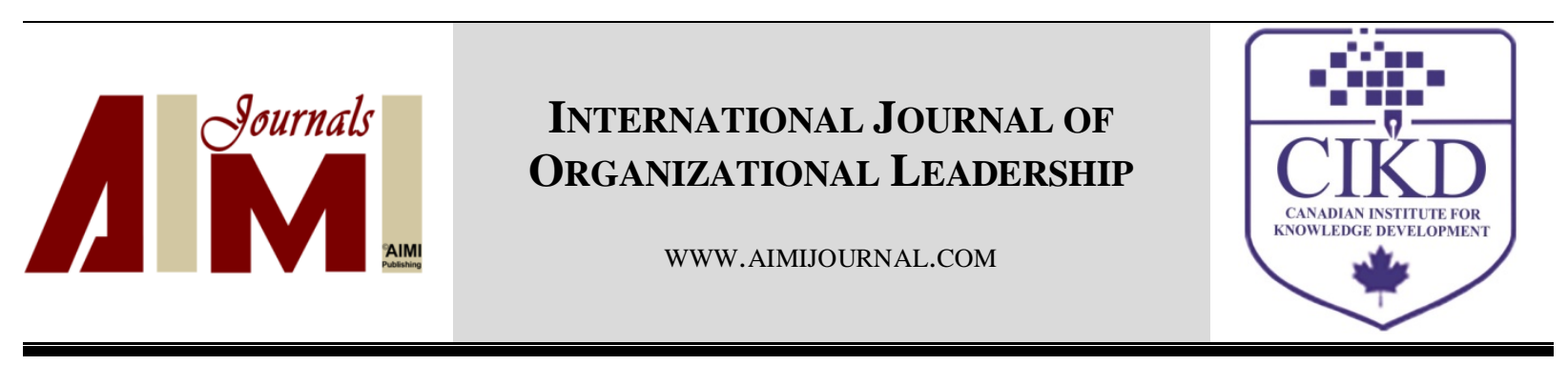

\title{
The Relationship between Whistleblowing and Organizational Citizenship Behaviour in Textile Sector
}

\author{
Mehmet Kiziloglu
}

Dr. Pamukkale University, Denizli, Turkey

\begin{abstract}
\section{Keywords:}

Whistleblowing, Organizational Citizenship Behaviour, Textile Sector, SME

\section{Received}

28 May 2018

Received in revised form 01 November 2018

Accepted

15 November 2018

Correspondence:

The aim of this research is to examine the relationship between whistleblowing and organizational citizenship behaviors in textile sector operating in Denizli province. The textile production and sales have always been placed on the top for the economic structure in Denizli. One of the important concepts of whistleblowing can be defined as revealing illegal and immoral practices in an organization. The concept of Organizational Citizenship Behavior (OCB) is defined as the assumption by employees of positive roles toward the organization about issues that do not fall within their own area of duty, on a voluntary basis and without having any expectation. The study used an empirical approach which includes qualitative and quantitative methods of analyzing data. The data were gathered through surveys from $12 \mathrm{SME}$ firms in textile sector. İn total, 192 useable surveys were obtained. The results revealed that there are statistically significant relationships between whistleblowing and organizational citizenship behavior in textile sector.
\end{abstract} mkiziloglu@pau.edu.tr

(C)AIMI Journals

In recent years, news about illegal or non-ethical actions in the workplace all over the world has been reflected through the media to the whole public. Whistleblowing may be defined as revealing illegal or non-ethical actions, behaviors and activities either internal or external report to take the necessary precautions. Whistleblowing which is carried out to remove or minimize the inconvenience, can be considered a conscientious activity. Within this concept, organizational citizenship behavior is also gaining importance. It is clear that in the success of today's organizations, it is becoming more and more important for employees to engage in the task of doing good things only on behalf of the organization, as well as doing jobs within the 
job descriptions. It is closely related to the fact that employees voluntarily endeavor to work on behalf of the organization as a part of the organization, which is expressed in the literature by organizational citizenship behavior.

In individuals who exhibit organizational citizenship behavior: they think of others and try to do something on their behalf, they are willing to behave beyond their expected minimum role behavior, tolerate the dissatisfaction and discomfort between the organizational and nonorganizational persons with tolerance, they inform them before taking any actions and voluntarily participated in decisions and meetings by accepting themselves as responsible for events affecting the organization.

\section{Literature Review \\ Whistleblowing}

The term 'whistleblowing' was first used in 1963 in the USA in documents concerning internal security risks at a Senate committee. As a word, it means the police blowing the whistle against a criminal to prevent a crime (Hersh, 2002). Whistleblowing is defined as the communication of illegal and unethical behaviors and acts in an organization by people who have inform them to internal or external authorities so that those people should not cause harm to others within or outside the organization or to other organizations (Miceli \& Near, 1984). An employee of an organization revealing an unethical or unlawful practice in his organization is referred to as a whistleblower (Near \& Miceli, 1985). There must be at least four items for whistleblowing. These are whistleblower who make whist blow, an illegal or non-ethical action, members of organization who make these actions and an association to report (Dasgupta \& Kesharwani, 2010). Whistleblowing is not a thing that can only be in state sector. According to Dehn (2001), every organization can come to face wrongdoings actions which affect their members negatively, and also according to Aktan (2006) whistleblowing can be in private sector and non-profit organization.

Internal and external whistleblowing are two types of whistleblowing (Özdemir, 2013). It is defined as 'internal whistleblowing' when the employee reports illegal and non-ethical behaviors in the organization to the employer or to the relevant persons in the organization (Mansbach \& Bachner, 2010). External whistleblowing is defined as when the employee reports illegal and non-ethical behaviors in the organization to the relevant persons outside the organization. It refers to the state, the police, the written or visual media, or the judicial authorities (Mansbach \& Bachner, 2010). The written or verbal report of illegal or non-ethical behaviors and actions without any fear is called open whistleblowing but reporting by secreting identity is called implicit whistleblowing (Aktan, 2006).

\section{Organizational Citizenship Behaviour}

When studies on organizational citizenship behavior are examined, it is seen that the most common definition of organizational citizenship behavior is made by Organ (1988). According to Organ (1988), organizational citizenship behavior; individual behaviors based on volunteerism that are not explicitly and fully found in the formal reward system, encouraging the organization to perform its functions efficiently as a whole. The common point of the concept of organizational citizenship behavior is that these behaviors are seen as role-based 
behaviors that are exhibited in a voluntary and voluntary manner, and they contribute to organizational effectiveness (Sezgin, 2005).

Altruism: It is the most important form of citizenship behavior (Organ, 1988; Podsakoff, Mackenzie, Paine, \& Bachrach, 2000; Williams \& Anderson, 1991). Altruism is defined as the behavior of individuals who work together and face-to-face to help each other directly and willingly.

Conscientiousness: It refers to the willingness of the employee to do more than the minimum role required for the organization in accordance with rules and regulations (Organ, 1988).

Sportsmanship: It requires that you continue to work without complaining if there is a problem with the job and continue to maintain a positive attitude when things are not going well (Podsakoff et al., 2000).

Courtesy: Courtesy behaviors are individual behaviors aimed at preventing work-related problems that arise from other employees in the organization (Organ, 1988).

Civic Virtue: It is defined as the employees who accept themselves as responsible for events affecting the organization, voluntarily participate in decisions and meetings (Kidder \& Parks, 2001).

\section{The Relationship between Whistleblowing and Organizational Citizenship Behaviour}

In the early studies on organizational citizenship behavior, it is seen that organizational citizenship behavior is used together with 'good soldier syndrome' expression (Bateman \& Organ, 1983; Organ, 1988). Good soldier syndrome besides showing behaviors such as finding the wrongs of the employees, discussing with them, complaining them, includes social behaviors, finishing the work on time, being innovative, helping others, and volunteering (Acar, 2006). When the good soldier syndrome is defined, it is seen that the expressions such as finding the wrongs of the employees, discussing with them, complaining them are similar to whistleblowing. In this sense, the importance of the relationship between whistleblowing and organizational citizenship behavior is inevitable.

\section{Method}

\section{Research Goal}

This research examines whether there is a significant relationship between whistleblowing and organizational citizenship behavior. Research on the relationship between the two concepts is important, because this study has been carried out with the thought that there may be a harmony between the two concepts.

\section{Sample and Data Collection}

This study was performed on the textile firms operating in Denizli. The questionnaire method was used to collect the necessary data for the study. The data were collected by giving a questionnaire to 192 respondents. In the process of preparing the questionnaire, the research on organizational citizenship behavior scale which was first used by Organ was employed. The questionnaire has 5 sub-dimensions consisting of 24 questions. The other is whistleblowing scale which has 9 questions, which in Park, Rehg, and Lee's study (2005) called Whistleblowing at Workplaces and a Practice. İn total, 192 questionnaires were evaluated for the study and the necessary analyses were performed with the SPSS software package. 


\section{Results}

In this section of the study, demographic findings, results of reliability, correlation between whistleblowing and organizational citizenship behavior and sub-dimensions are investigated. Table 1 presents the demographic information about the employee.

Table 1

Demographic Findings on the Employees

\begin{tabular}{|c|c|c|c|c|c|}
\hline Age & $\mathbf{n}$ & $\%$ & Gender & $\mathbf{n}$ & $\%$ \\
\hline $21-30$ & 62 & 32,3 & Male & 105 & 54,7 \\
\hline $31-40$ & 75 & 39,0 & Female & 87 & 45,3 \\
\hline $41-50$ & 32 & 16,7 & Time Served in the Business & $\mathbf{n}$ & $\%$ \\
\hline 51 and above & 23 & 12,0 & Less than 1 year & 11 & 5,8 \\
\hline Marital Status & $\mathbf{n}$ & $\%$ & $1-3$ years & 58 & 30,2 \\
\hline Married & 97 & 50,5 & 4-6 years & 63 & 32,8 \\
\hline Single & 78 & 40,6 & $7-10$ years & 32 & 16,7 \\
\hline Divorced & 17 & 8,9 & 10 years and above & 28 & 14,5 \\
\hline Educational Background & $\mathbf{n}$ & $\%$ & Total Time Served & $\mathbf{n}$ & $\%$ \\
\hline Primary & 27 & 14,0 & $1-5$ years & 61 & 31,8 \\
\hline High School & 76 & 39,6 & $6-10$ years & 82 & 42,8 \\
\hline Undergraduate & 68 & 35,4 & 11-20 years & 36 & 18,7 \\
\hline Postgraduate & 21 & 11,0 & 21 years and above & 13 & 6,7 \\
\hline Total & 192 & 100 & Total & 192 & 100 \\
\hline
\end{tabular}

As shown in Table 1, the majority is males with 105 (54.7\%), the number of females is 87 (45.3\%). It was found that 97 (50.5\%) of the participants are married, 78 (40.6\%) of them are single. It was also observed that 62 (32.3\%) are within the age group of 21-30; 75 (39.0\%) are within the age group of $31-40$, and they constitute $71 \%$ of all participants. The educational backgrounds of the employees participated in the research indicated that 76 (39.6\%) of them graduated from high school or equivalent, 68 (35.4\%) are undergraduates, $21(11.0 \%)$ are postgraduates.

Given the time the participants worked in the business, it was found that 58 (30.2\%) worked there for 1-3 years; 63 (32.8\%) for 4-6 years; 32 (16.7\%) for 7-10 years; and 28 (14.5\%) for 10 years and above. For the total working experiences of the participants, 61 (31.8\%) of them have experience of $1-5$ years; 82 (42.8\%) of 6-10 years; 36 (18.7\%) of $11-20$ years; and 13 $(6.7 \%)$ of 21 years and above.

\section{Reliability of the Questionnaires}

The scales used to measure whistleblowing and organizational citizenship behavior were tested for reliability. No questions were raised because the 9 questions to measure whistleblowing and the 24 questions included in the organizational citizenship behavior scale provide the expected levels of reliability. The results of reliability analysis for these scales are presented in Table 2. 
Whistleblowing and Organizational Citizenship Behavior Questionnaire Reliability Results, Mean and Standard Deviation Values

\begin{tabular}{lcccc}
\hline & $\begin{array}{c}\text { Number of } \\
\text { Questions }\end{array}$ & $M$ & $S D$ & Alpha \\
\hline Whistleblowing & 9 & 2.95 & 5.48 & .85 \\
Organizational Citizenship Behavior & 24 & 4.03 & 7.72 & .81 \\
\hline
\end{tabular}

An alpha value of .6 indicating reliability coefficients of whistleblowing and organizational citizenship behavior scales above .6 and an acceptable value for research can be seen from Table 2.

\section{Results of Correlation between Whistleblowing and Organizational Citizenship Behavior}

Correlation analysis for testing hypotheses are presented in the Table 3.

Table 3

Results of Correlation

\begin{tabular}{|c|c|c|c|c|c|c|c|}
\hline & & OCB & Altruism & Conscientiousness & Sportsmanship & Courtesy & Civic Virtue \\
\hline \multirow{3}{*}{ Whistleblowing } & Pearson / Spearman & .256 & .086 & .334 & 053 & .064 & .382 \\
\hline & $\mathrm{p}$ & .475 & .612 & .048 & .429 & .846 & .039 \\
\hline & $\mathrm{N}$ & 192 & 192 & 192 & 192 & 192 & 192 \\
\hline
\end{tabular}

Accoding to the correlation analysis presented in Table 3, there is a positive and low-level ( $p=$ 256) relationship between whistleblowing and organizational citizenship behavior. Also, there is a significant and positive relationship at low level between whistleblowing and conscientiousness $(p=.334)$ and civic virtue $(p=382) .(p<.05)$.

\section{Conclusion}

As defined already, whistleblowing refers to as the disclosure by organization members (former or current) of illegal, immoral, or illegitimate practices under the control of their employers, to persons or organizations that may be able to affect action. The other important concept is the organizational citizenship behavior which refers to employees' behavior that is more discretionary, is less likely to be formally linked with organizational rewards, and contributes to the organization by promoting a positive social and psychological climate.

As the results of this study revealed there is a positive relationship at low level between whistleblowing and organizational citizenship behavior. This result can be interpreted as the fact that employees who show organizational citizenship behavior tend to be whistleblowers but avoid it because of the organizational culture and the anxiety they have about employees. In addition, there is a significant and positive relationship at low level between whistleblowing and dimension of conscientiousness and civic virtue. This result can be interpreted that employees who has conscientiousness and civic virtue behaviour think that unethical and illegal behaviors within the organization cannot be solved within the organization; thus, they prefer to report outside the organization.

This research has produced consistent results with previous research although not much research has been conducted about relationship between whistleblowing and OCB. In a study, Aktan (2006) concluded that whistleblowing is a kind of civic virtue behaviour. Ozsoy and Beduk (2015) reported a positive relationship at low level between whistleblowing and OCB and sub dimension of civic virtue. Ertürk (2016) reported a positive relationship at low level 
between whistleblowing and OCB. The results of our research are consistent with the results of previous studies. Unlike other studies, there is a relationship between conscientiousness and whistleblowing. This result can be interpreted that conscientious employees who have conscience will not remain indifferent to unethical and illegal behaviors that may occur in the organization.

\section{References}

Acar, A. Z. (2006). Örgütssel yurttaşlık davranışı: Kavramın gelişimi ile kişisel ve örgütsel etkileri [organizational citizenship behavior: Development of concept and 1ts personal and organizational effects]. Doğuş Üniversitesi Dergisi, 7(1), 1-14.

Aktan, C. C. (2006). Organizasyonlarda Yanlış Uygulamalara Karşı Bir Sivil Erdem, Ahlaki Tepki Ve Vicdani Red Davranışı: Whistleblowing [A Civil Virtue, Moral Response, and Conscientious Objection against Misapplication in Organizations: Whistleblowing]. Mercek Dergisi, 1-13.

Bateman, T. S., \& Organ, D. W. (1983). Job satisfaction and the good soldier: The relationship between affect and employee 'citizenship'. Academy of Management Journal, 26(4), 587-595.

Dasgupta, S., \& Kesherwavi, A. (2010). Whistleblowing: A survey of literature. The IUP Journal of Corporate Governance, 4(4), 58-70.

Dehn, G. (2001). Whistleblowing: A New Perspective. Public Concern, 1-13.

Ertürk, A. (2016). The Relationship between Whistleblowing and Organizational Citizenship Behavior For High School Teachers, Journal of Educational Sciences Research, 6 (1), 1-22.

Hersh, M. A. (2002). Whistleblowers-heroes or traitors? individual and collective responsibility for ethical behaviour. Annual Reviews in Control, 26(2), 243-262.

Kidder, D., \& Parks, J. M. (2001). The good soldier: Who is she? Journal of Organizational Behavior, 228, 939-959.

Mansbach, A., \& Bachner, G. Y. (2010). Internal or external whistleblowing: Nurses’ willingness to report wrongdoing. Nursing Ethics, 17(4), 483-490.

Miceli, M. P., \& Near, J. P. (1984). The relationships among beliefs, organizational position, and whistleblowing status: A discriminant analysis. Academy of Management Journal, 27, 687-705.

Near, J. P., \& Miceli, M. P. (1985). Organizational dissidence: The case of whistleblowing. Journal of Business Ethics, 4(1), $1-16$.

Organ, D. W. (1988). Organizational citizenship behavior: The good soldier syndrome. Lexington, MA: Lexington Books

Özdemir, M. (2013). The relationship of organizational corruption with organizational dissent and whistleblowing in Turkish schools. Cukurova University Faculty of Education Journal, 42(1), 74-84.

Ozsoy, N., \& Beduk, A. (2015). The relationship between whistleblowing and organizational citizenship behaviour. International Journal of Academic Research in Business and Social Sciences, 5(4), 193-203.

Park, H., Rehg, M. T., \& Lee, D. (2005). The influence of Confucian ethics and collectivism on whistleblowing intentions: A study of South Korean public employees. Journal of Business Ethics, 58(4), 387-403.

Podsakoff, P. M., Mackenzie S. B., Paine J. B., \& Bachrach, D. G. (2000). Organizational citizenship behaviors: A critical review of the theoretical and empirical literature and suggestions for future research. Journal of Management, 26(3), 513563.

Sezgin, F. (2005). Örgütsel Vatandaşlık Davranışları: Kavramsal Bir Çözümleme ve Okul Açısından Bazı Çıkarımlar [Organizational Citizenship Behaviors: A Conceptual Analysis and Some Implications for the School]. Gazi Egitim Fakultesi Dergisi, 25(1), 317-339.

Williams, L. J., \& Anderson, S. E. (1991). Job satisfaction and organizational commitment as predictors of organizational citizenship and in-role behaviors. Journal of Management, 17, 601- 617. 